\title{
Gamma Knife surgery for clival epidural-osseous dural arteriovenous fistulas
}

\author{
Cheng-Chia Lee, MD, ${ }^{1,4}$ Ching-Jen Chen, MD, ${ }^{6}$ Shao-Ching Chen, MD, ${ }^{1}$ Huai-Che Yang, MD, ${ }^{1,4}$ \\ Chung Jung Lin, MD, ${ }^{2,4}$ Chih-Chun Wu, MD, ${ }^{2,4}$ Wen-Yuh Chung, MD, ${ }^{1,4}$ Wan-Yuo Guo, MD, PhD, ${ }^{2,4}$ \\ David Hung-Chi Pan, MD, ${ }^{1,5}$ Cheng-Ying Shiau, MD, ${ }^{3,4}$ and Hsiu-Mei Wu, MD ${ }^{2,4}$
}

\begin{abstract}
Departments of ${ }^{1}$ Neurosurgery, ${ }^{2}$ Radiology, and ${ }^{3}$ Radiation Oncology, Taipei Veterans General Hospital; ${ }^{4}$ School of Medicine, National Yang-Ming University; ${ }^{5}$ Taipei Medical University-Shuang Ho Hospital, Taipei, Taiwan; and ${ }^{6}$ Department of Neurological Surgery, University of Virginia Health System, Charlottesville, Virginia
\end{abstract}

\begin{abstract}
OBJECTIVE Clival epidural-osseous dural arteriovenous fistula (DAVF) is often associated with a large nidus, multiple arterial feeders, and complex venous drainage. In this study the authors report the outcomes of clival epidural-osseous DAVFs treated using Gamma Knife surgery (GKS).

METHODS Thirteen patients with 13 clival epidural-osseous DAVFs were treated with GKS at the authors' institution between 1993 and 2015. Patient age at the time of GKS ranged from 38 to 76 years (median 55 years). Eight DAVFs were classified as Cognard Type I, 4 as Type Ila, and 1 as Type Ila $+b$. The median treatment volume was $17.6 \mathrm{~cm}^{3}$ (range $6.2-40.3 \mathrm{~cm}^{3}$ ). The median prescribed margin dose was $16.5 \mathrm{~Gy}$ (range 15-18 Gy). Clinical and radiological follow-ups were performed at 6 -month intervals. Patient outcomes after GKS were categorized as 1) complete improvement, 2) partial improvement, 3) stationary, and 4) progression.
\end{abstract}

RESULTS All 13 patients demonstrated symptomatic improvement, and on catheter angiography 12 of the 13 patients had complete obliteration and 1 patient had partial obliteration. The median follow-up period was 26 months (range 14-186 months). The median latency period from GKS to obliteration was 21 months (range 8-186 months). There was no intracranial hemorrhage during the follow-up period, and no deaths occurred. Two adverse events were observed following treatment, and 2 patients required repeat GKS treatment with eventual complete obliteration.

CONCLUSIONS Gamma Knife surgery offers a safe and effective primary or adjuvant treatment modality for complex clival epidural-osseous DAVFs. All patients in this case series demonstrated symptomatic improvement, and almost all patients attained complete obliteration.

https://thejns.org/doi/abs/10.3171/2017.1.JNS161346

KEY WORDS dural arteriovenous fistula; epidural; Gamma Knife; osseous; treatment outcome; stereotactic radiosurgery

$\mathrm{D}$ URAL arteriovenous fistulas (DAVFs) are direct arteriovenous shunts between the meningeal arteries and the dural venous sinuses or leptomeningeal veins. ${ }^{1,11}$ Annual hemorrhage rates of up to $18 \%$ have been estimated for DAVFs. ${ }^{4,25}$ The clinical presentation of DAVF is variable depending on its location and venous drainage pattern. The presence or absence of cortical venous reflux is the basis of current DAVF classification systems. ${ }^{3,6}$
In contrast to the dural location of arteriovenous shunts in classic DAVFs, clival epidural-osseous DAVFs are located extradurally and can involve the bony clivus. Fistulas are often observed between meningeal arteries and intraosseous diploic veins or transosseous emissary veins. ${ }^{12}$ Venous drainage patterns and clinical manifestations of clival epidural-osseous DAVFs can be similar to those of classic DAVFs. ${ }^{9,20,26}$ However, given the rarity of clival epidural-osseous DAVFs, outcomes for these lesions are

ABBREVIATIONS CN = cranial nerve; DAVF = dural arteriovenous fistula; GKS = Gamma Knife surgery; MRA = MR angiography; PICA = posterior inferior cerebellar artery; TOF = time of flight; VA = vertebral artery.

SUBMITTED June 4, 2016. ACCEPTED January 5, 2017.

INCLUDE WHEN CITING Published online June 16, 2017; DOI: 10.3171/2017.1.JNS161346. 
TABLE 1. Demographics of 13 patients with intraosseous dAVFs

\begin{tabular}{|c|c|c|c|c|}
\hline $\begin{array}{l}\text { Case } \\
\text { No. }\end{array}$ & $\begin{array}{c}\text { Age (yrs) } \\
\text { Sex }\end{array}$ & Clinical Presentation & Prior Treatment & $\begin{array}{c}\text { Cognard } \\
\text { Type }\end{array}$ \\
\hline 1 & $52, \mathrm{~F}$ & Occipital headache, pulsatile tinnitus after head trauma w/ skull base fracture & None & I \\
\hline 2 & $55, \mathrm{~F}$ & Occipital headache, neck pain, pulsatile tinnitus & None & I \\
\hline 3 & $38, \mathrm{M}$ & Headache, pulsatile tinnitus, dizziness & None & I \\
\hline 4 & $65, \mathrm{~F}$ & Pulsatile tinnitus & Jugular vein ligation & lla+b \\
\hline 5 & $57, \mathrm{M}$ & Occipital headache, pulsatile tinnitus, hearing impairment w/ 15-dB decrease in rt ear & None & I \\
\hline 6 & $56, \mathrm{M}$ & Pulsatile tinnitus, redness \& swelling of rt eye & None & I \\
\hline 7 & $53, \mathrm{M}$ & Pulsatile tinnitus, bilat hearing impairment, history of meningitis \& head trauma & None & Ila \\
\hline 8 & $52, \mathrm{M}$ & Headache, pulsatile tinnitus, dizziness & $1 \times$ transarterial embolization & I \\
\hline 9 & $76, \mathrm{M}$ & Redness, chemosis, \& mild proptosis of It eye, visual acuity impairment before GKS & $2 \times$ transarterial embolization & Ila \\
\hline 10 & $61, F$ & $\begin{array}{l}\text { Redness, chemosis, \& mild proptosis of rt eye, double vision, exophthalmos, rt hearing } \\
\text { impairment }\end{array}$ & None & Ila \\
\hline 11 & $56, \mathrm{~F}$ & Pulsatile tinnitus, tongue deviation & None & I \\
\hline 12 & $47, \mathrm{~F}$ & Pulsatile tinnitus & None & I \\
\hline 13 & $38, M$ & Pulsatile tinnitus, congestion of rt eye & None & Ila \\
\hline
\end{tabular}

limited in the literature; only 25 cases have been reported, and most were treated using endovascular embolization. $8,12,16,22,23$

Stereotactic radiosurgery is a common treatment for DAVFs, affording favorable rates of complete obliteration with low complication rates. ${ }^{2,10,13,14,19,24,28,29}$ Despite the multiple radiosurgical outcome series for DAVFs published in the literature, no dedicated radiosurgical outcome study for clival epidural-osseous DAVFs has been published. 10,17,28,29 Therefore, we undertook this study to evaluate the outcomes of Gamma Knife surgery (GKS) for clival epidural-osseous DAVFs.

\section{Methods}

\section{Patients Characteristics}

This study was approved by the institutional review board at the Taipei Veterans General Hospital. A total of 443 patients with intracranial DAVFs were treated with GKS at our institution between 1993 and 2015. Among these patients were $249(56 \%)$ with ventral type DAVFs, ${ }^{9}$ which comprised 236 cavernous sinus DAVFs (53\%) and 13 clival epidural-osseous DAVFs (3\%). Of these patients with clival epidural-osseous DAVFs, 7 (54\%) were male and $6(46 \%)$ were female. Indications for GKS treatment included intolerable symptoms (ocular symptoms, headaches, and pulsatile tinnitus), focal neurological deficit, and residual shunt after prior therapies. There were no prior intracranial hemorrhages. Two patients $(15.4 \%)$ had prior histories of head trauma. Three patients underwent prior endovascular embolization or ipsilateral jugular vein ligation for their DAVFs; however, cerebral angiography demonstrated residual fistulas. All clival epidural-osseous DAVFs were classified using the Cognard classification: 8 Type I, 4 Type IIa, and 1 Type IIa+b. ${ }^{6}$ Patient age at the time of GKS treatment ranged from 38 to 76 years (median 55 years). The patient demographics are presented in Table 1. Detailed angiographic features including arterial supply and venous drainage are listed in Table 2 . Ten
DAVFs had more than 5 supply arteries, and most were small branches from the external carotid arteries and the vertebral arteries (VAs).

\section{Stereotactic Radiosurgery}

Stereotactic radiosurgery was performed using the Gamma Knife (Elekta AB) Model B (from 1993 to 2006) or Model 4C (after 2007). Target localization was achieved by integrating imaging data from stereotactic noncontrasted MRI, time-of-flight (TOF) MR angiography (MRA), and catheter cerebral angiography. All patients were treated with the goal of complete fistula obliteration. The treatment volume, by definition, included all abnormal arteriovenous shunts in the epidural clival region along with the immediate early draining veins. The proximal arterial feeders and distal draining veins were excluded from the treatment volume. The median treatment volume for DAVFs was $17.6 \mathrm{~cm}^{3}$ (range $6.2-40.3 \mathrm{~cm}^{3}$ ). The median prescribed margin dose was 16.5 Gy (range 15-18 Gy). The median number of isocenters was 10 (range 2-23). Figure 1 illustrates the GammaPlan for a typical case of clival epidural-osseous DAVF. Comprehensive radiosurgical treatment parameters are outlined in Table 3.

For evaluating possible complications, the details of radiation dose in related critical neurovascular structures are listed in Table 4. The mean and maximum radiation doses to the cranial nerve $(\mathrm{CN}) \mathrm{IX}-\mathrm{XI}$ complex (pars nervosa and medial part of the pars vascularis of the jugular foramen) were 22.7 and $29.0 \mathrm{~Gy}$, respectively. The mean and maximum radiation doses to CN XII (hypoglossal canal) were 24.8 and $28.0 \mathrm{~Gy}$, respectively. The mean volume of internal carotid artery and VA exposed to radiation $>18$ Gy was 31 and $65 \mathrm{~mm}^{3}$, respectively. The mean volume of brainstem exposed to radiation > 12 Gy was $166 \mathrm{~mm}^{3}$.

\section{Follow-Up}

Clinical and radiological (MRI and MRA) follow-ups were performed at 6-month intervals. Catheter angiogra- 
TABLE 2. Angiographic features in 13 patients with intraosseous DAVFs

\begin{tabular}{|c|c|c|c|c|c|c|c|c|c|}
\hline \multirow{2}{*}{$\begin{array}{l}\text { Case } \\
\text { No. }\end{array}$} & \multirow[b]{2}{*}{ Laterality } & \multicolumn{6}{|c|}{ Arterial Supply } & \multirow[b]{2}{*}{ Venous Drainage } & \multirow{2}{*}{$\begin{array}{c}\text { Stenosis/ } \\
\text { Occlusion } \\
\text { of Draining } \\
\text { Vein }\end{array}$} \\
\hline & & Rt ICA & Rt ECA & Lt ICA & Lt ECA & Rt VA & Lt VA & & \\
\hline 1 & Rt & None & APhA, OA, PAA, IMA & None & APhA, PAA, IMA & PMA, MDB & MDB & Rt IJV & No \\
\hline 2 & Rt & None & $\begin{array}{l}\text { APhA, OA, PAA, } \\
\text { IMA, STA }\end{array}$ & None & APhA, PAA, IMA & PMA, MDB & $\begin{array}{l}\text { PMA, } \\
\text { MDB }\end{array}$ & $\begin{array}{l}\text { Ant cervical epidural venous plex- } \\
\text { us, suboccipital venous plexus, rt } \\
\text { ACV \& PCV, rt \& It IJV }\end{array}$ & No \\
\hline 3 & $\mathrm{Lt}$ & None & APhA, IMA & Yes & $\begin{array}{l}\text { APhA, OA, PAA, } \\
\text { IMA }\end{array}$ & PMA, MDB & MDB & $\begin{array}{l}\text { Ant cervical epidural venous } \\
\text { plexus, suboccipital venous } \\
\text { plexus, It ACV \& PCV }\end{array}$ & No \\
\hline 4 & Rt & None & APhA, OA, IMA & None & APhA, IMA & MDB & None & PCV & Yes \\
\hline 5 & Rt & Yes & APhA, OA, IMA & Yes & APhA & MDB & MDB & Rt ACV, suboccipital venous plexus & No \\
\hline 6 & Rt & Yes & APhA, OA, PAA, IMA & Yes & APhA, PAA, IMA & PMA, MDB & MDB & Rt ACV, IPS & No \\
\hline 7 & Rt & None & APhA, OA, PAA, IMA & None & IMA & PMA, MDB & MDB & Rt IJV & No \\
\hline 8 & $\mathrm{Rt}$ & None & APhA, IMA & None & APhA, IMA & ACBs & ACBs & PCV into jugular bulb & No \\
\hline 9 & $\mathrm{Lt}$ & None & APhA & None & $\begin{array}{l}\text { APhA, OA, PAA, } \\
\text { IMA }\end{array}$ & MDB & $\begin{array}{l}\text { PMA, } \\
\text { MDB }\end{array}$ & $\begin{array}{l}\text { Rt IPS, CS, It superior petrosal } \\
\text { sinus }\end{array}$ & No \\
\hline 10 & Rt & None & APhA, OA, PAA, IMA & None & APhA & PMA, MDB & MDB & Rt ACV, IPS, rt IJV & No \\
\hline 11 & Rt & None & APhA, OA, PAA & None & $\begin{array}{l}\text { APhA, OA, PAA, } \\
\text { IMA }\end{array}$ & PMA, MDB & MDB & Rt ACV, IPS & No \\
\hline 12 & $\mathrm{Lt}$ & None & None & None & APhA, IMA & None & MDB & Lt IJV & No \\
\hline 13 & Rt & None & APhA & None & None & None & None & Rt IPS, CS, SOV & No \\
\hline
\end{tabular}

$\mathrm{ACB}=$ ascending cervical branch; $\mathrm{ACV}$ = anterior condylar vein; $\mathrm{Ant}=$ anterior; $\mathrm{APhA}=$ ascending pharyngeal artery; $\mathrm{CS}=$ cavernous sinus; $\mathrm{ECA}=$ external carotid artery; ICA = internal carotid artery; IJV = internal jugular vein; IMA = internal maxillary artery; IPS = inferior petrosal sinus; $M D B=$ muscular-dural branch; $O A=0$ occipital artery; PAA = posterior auricular artery; PCV = posterior condylar vein; PMA = posterior meningeal artery; SOV = superior ophthalmic vein; STA = superficial temporal artery.

phy was performed only if complete obliteration of the DAVF was observed on MRI and MRA. For clival epidural-osseous DAVFs with venous drainage involving the ophthalmic vein, noninvasive color Doppler ultrasonography (CDU) was also performed at 6-month intervals to evaluate the direction of flow and velocity within the superior ophthalmic vein. Radiological imaging interpretations prior to treatment and at follow-ups were performed by experienced neuroradiologists (W.Y.G., H.M.W., C.J.L., and C.C.W.) at our institution. These interpretations were performed independently without knowledge of the patient's clinical status, which was assessed by neurosurgeons (C.C.L, H.C.Y., W.Y.C, and D.H.C.P.).

Patient outcomes after GKS were categorized as 1) complete improvement, indicating complete resolution of symptoms with complete obliteration of the DAVF on catheter angiography and/or MRA; 2) partial improvement, indicating partial resolution of clinical symptoms with $>50 \%$ obliteration of the DAVF on MRA; 3) stationary, indicating stable DAVF on follow-up MRA; and 4) progression, indicating enlargement or development of aggressive features of the DAVF on MRA.

\section{Results}

Follow-ups were performed in all 13 patients with clival epidural-osseous DAVFs, with a median follow-up period of 26 months (range 14-186 months). Among the 13 patients, 12 had complete improvement and 1 patient

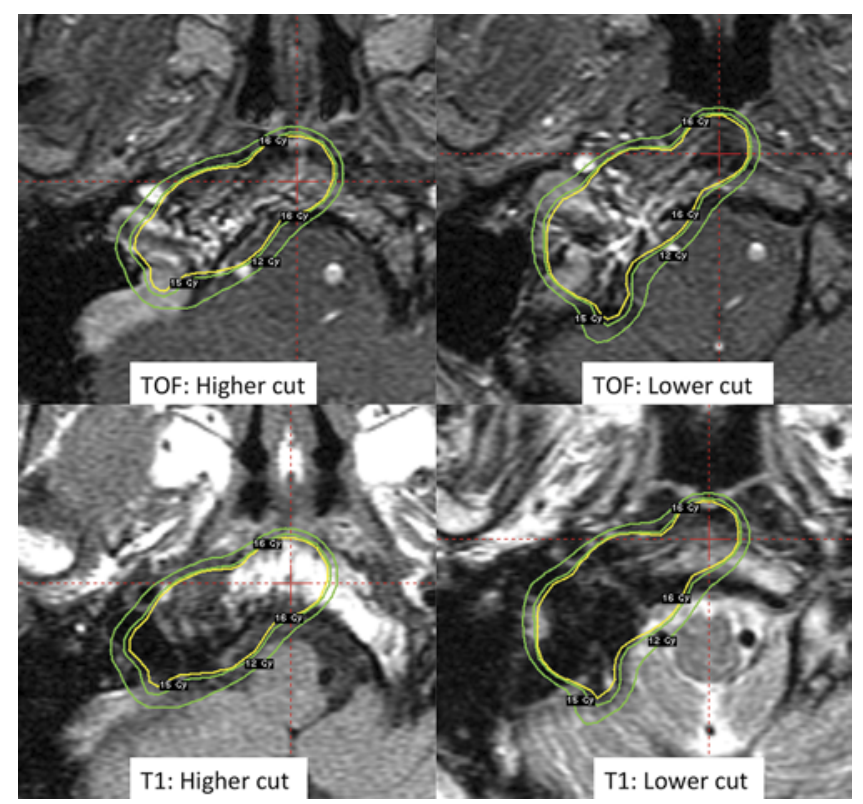

FIG. 1. Typical clival epidural-osseous DAVF dose plan. All nidus contents were covered within the planned treatment volume, including neurovascular structures within the jugular foramen. The radiosurgical volume denoted by yellow (55\% isodose line) was $11.7 \mathrm{ml}$, and the margin dose was $16 \mathrm{~Gy}$. With the narrowed space, keeping the brainstem under 12 Gy was necessary to avoid adverse radiation effects. Green lines indicate $12 \mathrm{~Gy}$ and $15 \mathrm{~Gy}$. Figure is available in color online only. 
TABLE 3. Treatment parameters and clinical outcomes in 13 patients with intraosseous DAVFs

\begin{tabular}{|c|c|c|c|c|c|c|c|}
\hline $\begin{array}{l}\text { Case } \\
\text { No. }\end{array}$ & $\begin{array}{l}\text { Radiation } \\
\text { Treatment } \\
\text { Vol }\left(\mathrm{cm}^{3}\right)\end{array}$ & $\begin{array}{l}\text { Margin } \\
\text { Dose } \\
\text { (Gy) }\end{array}$ & $\begin{array}{l}\text { Max } \\
\text { Dose } \\
\text { (Gy) }\end{array}$ & Obliteration* & $\begin{array}{l}\text { Latency Period } \\
\text { From GKS to } \\
\text { Obliteration (mos) }\end{array}$ & $\begin{array}{l}\text { Clinical } \\
\text { FU } \\
\text { (mos) }\end{array}$ & Clinical Outcome of Initial Symptoms \& Signs \\
\hline 1 & 11.7 & 16.0 & 29.1 & Total & 19 & 83 & Symptom free \\
\hline $2 \dagger$ & $40.3 / 18.1$ & $16.5 / 16.5$ & $28.5 / 29.5$ & Total & 51 & 58 & Symptom free \\
\hline 3 & 22.8 & 16.5 & 29.0 & Total & 25 & 25 & Symptom free \\
\hline 4 & 29.7 & 16.5 & 29.5 & Total & 21 & 103 & Symptom free \\
\hline 5 & 12.2 & 18.0 & 32.1 & Total & 25 & 87 & Symptom free \\
\hline 6 & 26.9 & 16.5 & 28.0 & Partial $>80 \%$ & 68 & 68 & Partial improvement in tinnitus \& ocular symptoms \\
\hline 7 & 17.9 & 16.5 & 29.5 & Total & 23 & 23 & $\begin{array}{l}\text { Improvement in ocular symptoms, but hearing impair- } \\
\text { ment remained }\end{array}$ \\
\hline 8 & 12.7 & 18.0 & 31.0 & Total & 16 & 62 & Symptom free \\
\hline 9 & 6.2 & 15.0 & 30.0 & Total & 15 & 21 & $\begin{array}{l}\text { Improvement in ocular symptoms, but visual acuity } \\
\text { remained stable }\end{array}$ \\
\hline 10 & 17.7 & 16.5 & 33.0 & Total & 13 & 19 & $\begin{array}{l}\text { Improvement in ocular symptoms, but hearing impair- } \\
\text { ment remained }\end{array}$ \\
\hline 11 & 10.8 & 16.5 & 28.5 & Total & 21 & 23 & Improvement in tinnitus, but tongue deviation remained \\
\hline 12 & 11.9 & 17.5 & 31.8 & Total & 8 & 14 & Symptom free \\
\hline $13 \ddagger$ & $17.6 / 7.9$ & $16.0 / 16.5$ & $29.1 / 29.0$ & Total & 186 & 187 & Symptom free \\
\hline
\end{tabular}

$\mathrm{FU}=$ follow-up.

* Defined by MRI, MRA, or catheter cerebral angiography.

$\dagger$ Patient underwent repeat GKS, attaining partial obliteration $>95 \%$ at the time, 39 months after the first GKS. Total obliteration was observed 51 months after the initial GKS.

$\ddagger$ Patient underwent repeat GKS, attaining partial obliteration $>80 \%$ at the time, 56 months after the first GKS. Total obliteration was observed 186 months after the initial GKS.

had partial improvement. The median latency period from GKS to obliteration was 21 months (range 8-186 months). Two patients (Cases 2 and 13) required repeat GKS treatment using similar radiation doses at 39 and 56 months after initial treatment, respectively. Both patients eventually attained obliteration at 51 and 186 months, respectively. Clinical outcomes are summarized in Table 3. An example of a patient (Case 1) with a right-sided clival epiduralosseous DAVFs treated with GKS, who attained complete obliteration at 19 months, is featured in Fig. 2.

TABLE 4. Radiation profile and complications in 13 patients with intraosseous DAVFs

\begin{tabular}{|c|c|c|c|c|c|c|c|c|c|}
\hline \multirow[b]{2}{*}{$\begin{array}{l}\text { Case } \\
\text { No. }\end{array}$} & \multicolumn{2}{|c|}{$\begin{array}{l}\text { CNs } \\
\mid \mathrm{X}-\mathrm{XI}\end{array}$} & \multicolumn{2}{|c|}{$\begin{array}{l}\mathrm{CN} \\
\mathrm{XII}\end{array}$} & \multicolumn{2}{|c|}{$\begin{array}{l}\text { Vol Receiving } \\
>18 \mathrm{~Gy}\left(\mathrm{~mm}^{3}\right)\end{array}$} & \multirow{2}{*}{$\begin{array}{l}\text { Vol w/in } \\
\text { Skull } \\
\text { Receiving } \\
>12 \mathrm{~Gy}\left(\mathrm{~cm}^{3}\right)\end{array}$} & \multirow{2}{*}{$\begin{array}{l}\text { Brainstem Vol } \\
\text { Exposed to } \\
>12 \mathrm{~Gy} \\
\text { Radiation }\left(\mathrm{mm}^{3}\right)\end{array}$} & \multirow[b]{2}{*}{ Complication } \\
\hline & $\begin{array}{c}\text { Mean } \\
\text { Dose (Gy) }\end{array}$ & $\begin{array}{l}\text { Max Dose } \\
\text { (Gy) }\end{array}$ & $\begin{array}{c}\text { Mean } \\
\text { Dose (Gy) }\end{array}$ & $\begin{array}{l}\text { Max Dose } \\
\text { (Gy) }\end{array}$ & VA & ICA & & & \\
\hline 1 & 27.0 & 29.1 & 17.9 & 28.7 & 9.8 & 585.7 & 15.6 & 51.2 & None \\
\hline 2 & $22.7 / 23.1$ & $28.0 / 30.1$ & $25.5 / 23.8$ & $26.9 / 29.1$ & $58.7 / 44.4$ & $65.0 / 0.0$ & $55.4 / 24.9$ & $1700 / 0$ & None \\
\hline 3 & 20.4 & 28.1 & 21.5 & 28.0 & 31.0 & 42.4 & 31.4 & 14.4 & None \\
\hline 4 & 24.4 & 29.0 & 20.0 & 26.7 & 118.6 & 370.6 & 40.8 & 286.1 & None \\
\hline 5 & 22.5 & 30.2 & 30.1 & 31.3 & 19.4 & 11.1 & 18.3 & 3.3 & None \\
\hline 6 & 21.0 & 26.4 & 20.1 & 27.3 & 64.6 & 529.6 & 37.0 & 236.5 & Lt PICA territory infarction \\
\hline 7 & 22.9 & 17.0 & 11.1 & 19.8 & 50.3 & 16.0 & 24.6 & 0 & None \\
\hline 8 & 29.0 & 31.1 & 26.8 & 28.0 & 0.0 & 378.4 & 19.1 & 0.8 & $\begin{array}{l}\text { Transient rt middle ear effusion, } \\
\text { transient dysphagia }\end{array}$ \\
\hline 9 & 12.3 & 23.0 & 28.3 & 29.2 & 43.1 & 0.0 & 7.8 & 0 & None \\
\hline 10 & 28.1 & 30.7 & 28.6 & 31.2 & 91.6 & 454.0 & 24.3 & 0 & None \\
\hline 11 & 18.1 & 24.3 & 24.8 & 27.4 & 1.1 & 28.7 & 14.9 & 31.9 & None \\
\hline 12 & 29.2 & 31.1 & 28.6 & 30.0 & 0.0 & 392.4 & 17.4 & 0 & None \\
\hline 13 & $21.9 / 21.9$ & $24.8 / 29.3$ & $18.8 / 19.8$ & $23.0 / 28.0$ & $0.0 / 0.0$ & $520.1 / 0.0$ & $23.5 / 10.9$ & $0 / 0$ & None \\
\hline Average & 22.7 & 29.0 & 24.8 & 28.0 & 31.0 & 65.0 & 24.4 & 166.0 & \\
\hline
\end{tabular}



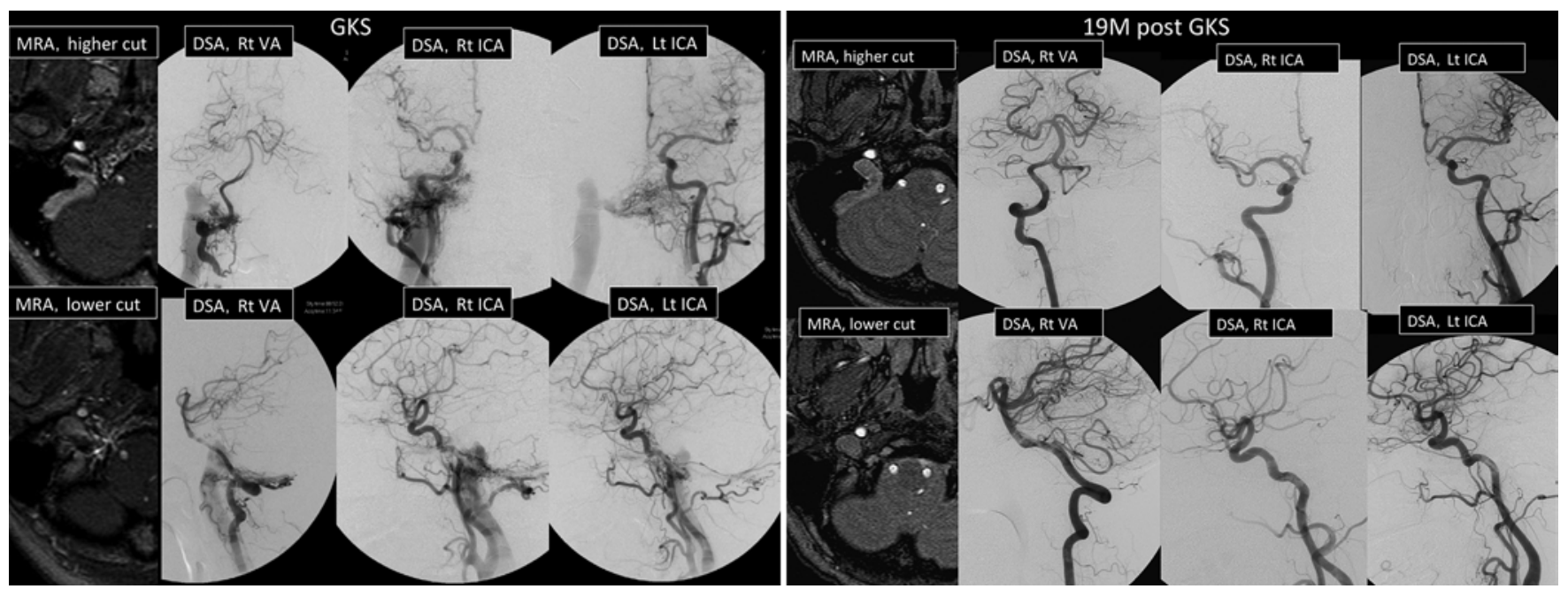

FIG. 2. Case 1. Images obtained in a 52-year-old woman with a right-sided Cognard Type I clival epidural-osseous DAVF. Axial TOF MRA images and VA and internal carotid artery injection cerebral angiograms, anteroposterior and lateral views, obtained in a patient treated with a margin dose and maximum dose of 16 and $29 \mathrm{~Gy}$, respectively. The target volume was $11.7 \mathrm{~cm}^{3}$. A gradual decrease in abnormal flow was noted on follow-up MRA images. Cerebral angiograms demonstrated complete obliteration at 19 months (19M). DSA = digital subtraction angiography; ICA = internal carotid artery.

No patient experienced intracranial hemorrhage during the follow-up period, and no deaths were observed. Two adverse events were observed following GKS treatment. One patient (Case 6) developed an ipsilateral (right) posterior inferior cerebellar artery (PICA) territory infarct with associated vertigo and gait ataxia at 51 months after treatment, and thrombosis of the right PICA was noted on MRI and MRA. The right VA volume that received a radiation dose $>18$ Gy was $64.6 \mathrm{~mm}^{3}$, which was not the highest in this study group (Table 4). Review of the patient's pretreatment images revealed a normal variant of hypoplastic VA that terminated at a hypoplastic PICA. The small caliber and acute angulation of the vessel may account for its vulnerability to the adverse effects of radiation.

The other patient (Case 8) had complete obliteration at 16 months; however, he developed ipsilateral middle ear effusion and transient dysphagia 26 months after GKS. The middle ear effusion was managed using a tympanostomy tube with the resolution of symptoms at 36 months. This patient underwent transarterial embolization of his DAVF prior to GKS. The mean and maximum radiation doses to his right CN IX-X complex were 29.0 and $31.1 \mathrm{~Gy}$, respectively. Similarly high radiation doses delivered to other patients (Cases 2 and 12) were without adverse event. For those who received repeat GKS, no $\mathrm{CN}$ dysfunction was observed. Therefore, we speculated that the transarterial embolization might have partially compromised the arterial blood supply to the lower CNs, thus rendering them more susceptible to the adverse effects of radiation. No patient developed radiation-induced parenchymal edema after GKS, including the patient with the Cognard Type IIa+b DAVF. No correlations were observed between obliteration and Cognard type or nidus size.

Repeat GKS was necessary for complete obliteration in 2 patients (Cases 2 and 13) at 39 and 56 months, respectively, after initial treatment. The patient in Case 2 had a DAVF with extensive involvement of the clivus epiduralosseous space and was irradiated with a treatment volume of $40.3 \mathrm{ml}$. At 39 months following initial treatment, the patient underwent repeat GKS for a small residual DAVF. Complete obliteration was achieved at 51 months from the initial GKS. The other patient (Case 13) had initial symptomatic resolution; however, he was lost to follow-up before demonstrating complete DAVF obliteration. Recurrent symptoms were noted approximately 50 months after initial GKS; thus, the patient underwent repeat GKS at 56 months. He was again lost to follow-up until 186 months from the initial GKS when complete obliteration was observed on MRI. No adverse radiation event was noted in these 2 patients up to 36 and 131 months after the second GKS, respectively.

\section{Discussion}

Dural arteriovenous malformation management should be individualized with consideration of its course based on location and angioarchitecture, clinical presentation, and risk-benefit profile of the specific treatment modality. It is generally accepted that DAVFs presenting with hemorrhage, cortical venous reflex, progressive neurological deficits, or increased intracranial pressure should be urgently treated using endovascular embolization, surgery, or a combination of the two, to provide immediate relief of venous congestion. For DAVFs refractory or not amenable to endovascular or surgical therapy, stereotactic radiosurgery offers favorable obliteration rates with low complication rates. Over the past 20 years, 443 patients with DAVFs were treated using GKS at our institution; a complete obliteration rate of $66 \%$ was achieved and an additional $33 \%$ of the patients had a reduction in DAVF size with symptomatic improvement. ${ }^{18}$ In a systematic review and meta-analysis of 729 patients with 743 DAVFs treated using stereotactic radiosurgery, a mean obliteration rate of $63 \%$ was observed by Chen et al. ${ }^{5}$ In the same study, complete obliteration of cavernous sinus and non-cavernous sinus DAVFs was achieved in $73 \%$ and $58 \%$ of pa- 
TABLE 5. Literature review of studies of clival epidural-osseous DAVFs

\begin{tabular}{|c|c|c|c|c|c|}
\hline $\begin{array}{l}\text { Authors } \\
\& \text { Year (no. } \\
\text { of cases) }\end{array}$ & $\begin{array}{l}\text { Type } \\
\text { of } \\
\text { Treatment }\end{array}$ & $\begin{array}{l}\text { Treatment } \\
\text { Parameter/Embolic } \\
\text { Materials }\end{array}$ & Obliteration Rate & Complication & Major Conclusion \\
\hline $\begin{array}{l}\text { Present } \\
\text { study } \\
\text { (13) }\end{array}$ & GKS & $\begin{array}{l}\text { Median margin dose of } \\
16.5 \mathrm{~Gy}\end{array}$ & $\begin{array}{l}92 \%(12 / 13) \text { complete } \\
\text { obliteration at median FU } \\
\text { of } 21 \text { mos }\end{array}$ & $\begin{array}{l}1 \text { PICA territory } \\
\text { infarction, } \\
1 \text { suspect } \\
\text { CN IX-X } \\
\text { dysfunction }\end{array}$ & $\begin{array}{l}\text { GKS is effective \& efficient for clival epidural- } \\
\text { osseous DAVFs; high obliteration rate \& few } \\
\text { complications noted; in some vulnerable cases } \\
\text { (nerves or vessels), radiation dose should be } \\
\text { reduced to avoid complications }\end{array}$ \\
\hline $\begin{array}{l}\text { Nerva et } \\
\text { al., } 2014 \\
\text { (1) }\end{array}$ & $\begin{array}{l}\text { Emboli- } \\
\text { zation }\end{array}$ & $\begin{array}{l}\text { Coils \& liquid embolic } \\
\text { material via percu- } \\
\text { taneous transfacial } \\
\text { approach }\end{array}$ & 1 complete obliteration & None & $\begin{array}{l}\text { Endovascular access to intraosseous DAVF is lim- } \\
\text { ited by size \& location of intraosseous vascular } \\
\text { pouches; direct transfacial approach under im- } \\
\text { age guidance facilitated access \& embolization, } \\
\text { which led to improvement in patient's symptoms }\end{array}$ \\
\hline $\begin{array}{l}\text { Jung et al., } \\
2009 \\
(6)\end{array}$ & $\begin{array}{l}\text { Emboli- } \\
\text { zation }\end{array}$ & Coil (transvenous) & $\begin{array}{l}4 \text { complete obliterations, } \\
1 \text { delayed complete } \\
\text { obliteration } 1 \text { mo later, } 1 \\
\text { partial obliteration }\end{array}$ & None & $\begin{array}{l}\text { Intraosseous DAVF could be completely cured w/ } \\
\text { transvenous embolization; for curative treat- } \\
\text { ment, intraosseous dilated venous pouch can } \\
\text { be target lesion for endovascular treatment }\end{array}$ \\
\hline $\begin{array}{l}\text { Shi et al., } \\
2009 \text { (1) }\end{array}$ & $\begin{array}{l}\text { Emboli- } \\
\text { zation }\end{array}$ & $\begin{array}{l}\text { Onyx \& stent (transar- } \\
\quad \text { terial) }\end{array}$ & 1 complete obliteration & None & $\begin{array}{l}\text { Combined technique of covered stent placement } \\
\text { \& Onyx transarterial embolization is valuable } \\
\text { for management of complex DAVFs supplied } \\
\text { by branches of both external \& internal carotid } \\
\text { arteries }\end{array}$ \\
\hline $\begin{array}{l}\text { Shi et al., } \\
2008 \\
(10)\end{array}$ & $\begin{array}{l}\text { Emboli- } \\
\text { zation }\end{array}$ & $\begin{array}{l}\text { Onyx in } 3 \text { cases (trans- } \\
\text { arterial), NBCA in } 3 \\
\text { (transarterial), coil } \\
\text { in } 2 \text { (transvenous), } \\
\text { particles in } 2 \text { (trans- } \\
\text { venous) }\end{array}$ & $\begin{array}{l}5 \text { complete anatomical } \\
\text { cures, } 1 \text { incomplete } \\
\text { anatomical cure, } 3 \text { partial } \\
\text { occlusions, } 1 \text { partial } \\
\text { occlusion progressed to } \\
\text { anatomical cure at } 7 \text { mos }\end{array}$ & None & $\begin{array}{l}\text { Clival DAVFs can be misdiagnosed as dural } \\
\text { cavernous sinus fistulas; best treatment is } \\
\text { transarterial embolization of dural feeders using } \\
\text { liquid embolic agents; transvenous occlusion of } \\
\text { cavernous sinus unnecessary in most cases }\end{array}$ \\
\hline $\begin{array}{l}\text { Tirakotai et } \\
\text { al., } 2005 \\
\text { (4) }\end{array}$ & Surgery & Transcondylar approach & $\begin{array}{l}3 \text { complete obliterations, } 1 \\
\text { significant flow reduction }\end{array}$ & 1 & $\begin{array}{l}\text { Occipitocervical fusion may be needed due to } \\
\text { extensive bone drilling }\end{array}$ \\
\hline $\begin{array}{l}\text { Ernst et al., } \\
1999 \text { (3) }\end{array}$ & $\begin{array}{l}\text { Emboli- } \\
\text { zation }\end{array}$ & $\begin{array}{l}\text { Coil in } 2 \text { cases (transve- } \\
\text { nous), combined coil } \\
\text { (transvenous) \& PVA } \\
\text { (transarterial) in } 1\end{array}$ & 3 complete obliterations & None & $\begin{array}{l}\text { Transvenous coil embolization curative in } 2 \text { of } 3 \\
\text { cases \& would seem to be treatment of choice } \\
\text { when venous access available }\end{array}$ \\
\hline
\end{tabular}

$\mathrm{NBCA}=\mathrm{N}$-butyl-2-cyanoacrylate; PVA = polyvinyl alcohol.

tients, respectively. Complete obliteration of DAVFs with and without corticovenous reflux was observed in $56 \%$ and $75 \%$ of patients, respectively.

Clival epidural-osseous arteriovenous fistulas represent a subset of intracranial arteriovenous fistulas with an extradural nidus location. These arteriovenous fistulas are commonly located near the jugular foramen and bony clivus and are often associated with a complex arterial supply and venous drainage. In the literature, endovascular embolization has been a popular treatment modality for patients with clival epidural-osseous DAVFs. ${ }^{8,12,16,22,23} \mathrm{De}-$ spite this, a limited number of embolization series have been published since 1999 (Table 5). Shi et al. reported favorable outcomes with transarterial embolization using liquid embolic agents, and transvenous occlusion of the cavernous sinus was unnecessary in most cases. ${ }^{23}$ In 2009 the same authors described a rare case treated with a stent and Onyx. ${ }^{22}$ In a case series of 6 patients treated using transvenous embolization, Jung et al. documented complete obliteration in 4 patients, delayed obliteration in 1 , and partial obliteration in $1 .{ }^{12}$ Treatment of clival epiduralosseous DAVFs of the skull base can be technically challenging given the complexity and tortuosity of the multiple arterial feeders and draining veins within the bone..$^{16,21}$ Most patients with clival epidural-osseous DAVFs in our case series had more than 5 arterial feeders, most of them small-caliber branches from the external carotid arteries or VAs, which also supply the lower CNs. Incomplete obliteration of DAVFs following endovascular embolization and/or surgical intervention can lead to fistula recurrence as a result of increased vascular growth factor expression induced by local ischemia. ${ }^{15,27}$ In addition, the sacrifice of functioning draining veins with transvenous embolization and/or surgical intervention can be associated with increased venous congestion and the development of neurological deficits. ${ }^{11}$ Thus, for clival epiduralosseous DAVFs without aggressive angiographic features, stereotactic radiosurgery may represent a suitable first-line alternative treatment.

In this case series, we presented the outcomes of 13 
patients with clival epidural-osseous DAVFs treated with GKS. All 13 patients demonstrated symptomatic improvement, and 12 of the patients achieved complete obliteration on catheter angiography. Repeat GKS treatment in 2 patients was necessary for complete obliteration. Because of the extradural location of these lesions, radiation-induced injury to the brain parenchyma is infrequent. Although the lower CNs can tolerate higher radiation doses, their exact upper limit of tolerance remains unknown. In this case series, most of the CNs within the treatment field were exposed to radiation doses $>20$ Gy. No untoward CN dysfunction was noted, except in 1 patient who had undergone partial transarterial embolization prior to GKS who had transient middle ear effusion and subjective dysphagia. Congenital vascular variations within the treatment volume may also be associated with an increased risk of delayed ischemia. This study represents the first case series dedicated to the radiosurgical outcomes of clival epiduralosseous DAVFs.

\section{Study Limitations}

It is important to recognize the limitations of our study. It was retrospective in design, with all the limitations and weaknesses inherent to retrospective studies. The small number of patients and the heterogeneous venous drainage patterns and arterial feeders preclude appreciable subgroup analyses. In addition, this case series was a singlecenter experience, and the generalizability of our findings to other populations is limited. Recent advances in imaging, such as more sophisticated MR sequences (for example, MRA and perfusion studies) and higher field strength magnets, may not have been available at patient follow-ups and may represent a limitation in the estimation of latency to complete DAVF obliteration.

\section{Conclusions}

The complexity and tortuosity of the multiple arterial feeders and draining veins of clival epidural-osseous DAVFs may not be amenable to endovascular embolization or surgical intervention. Gamma Knife surgery provides a safe and effective minimally invasive therapeutic modality for these complex lesions. All patients in this case series demonstrated symptomatic improvement, and almost all patients attained complete obliteration. Gamma Knife surgery is a suitable primary or adjuvant treatment for clival epidural-osseous DAVFs.

\section{References}

1. Awad IA, Little JR, Akarawi WP, Ahl J: Intracranial dural arteriovenous malformations: factors predisposing to an aggressive neurological course. J Neurosurg 72:839-850, 1990

2. Barcia-Salorio JL, Soler F, Barcia JA, Hernández G: Stereotactic radiosurgery for the treatment of low-flow carotidcavernous fistulae: results in a series of 25 cases. Stereotact Funct Neurosurg 63:266-270, 1994

3. Borden JA, Wu JK, Shucart WA: A proposed classification for spinal and cranial dural arteriovenous fistulous malformations and implications for treatment. J Neurosurg 82:166179, 1995

4. Brown RD Jr, Wiebers DO, Nichols DA: Intracranial dural arteriovenous fistulae: angiographic predictors of intracranial hemorrhage and clinical outcome in nonsurgical patients. J Neurosurg 81:531-538, 1994

5. Chen CJ, Lee CC, Ding D, Starke RM, Chivukula S, Yen CP, et al: Stereotactic radiosurgery for intracranial dural arteriovenous fistulas: a systematic review. J Neurosurg 122:353362,2015

6. Cognard C, Gobin YP, Pierot L, Bailly AL, Houdart E, Casasco A, et al: Cerebral dural arteriovenous fistulas: clinical and angiographic correlation with a revised classification of venous drainage. Radiology 194:671-680, 1995

7. Duffau H, Lopes M, Janosevic V, Sichez JP, Faillot T, Capelle $\mathrm{L}$, et al: Early rebleeding from intracranial dural arteriovenous fistulas: report of 20 cases and review of the literature. J Neurosurg 90:78-84, 1999

8. Ernst R, Bulas R, Tomsick T, van Loveren H, Aziz KA: Three cases of dural arteriovenous fistula of the anterior condylar vein within the hypoglossal canal. AJNR Am J Neuroradiol 20:2016-2020, 1999

9. Geibprasert S, Pereira V, Krings T, Jiarakongmun P, Toulgoat F, Pongpech S, et al: Dural arteriovenous shunts: a new classification of craniospinal epidural venous anatomical bases and clinical correlations. Stroke 39:2783-2794, 2008

10. Guo WY, Pan DH, Wu HM, Chung WY, Shiau CY, Wang $\mathrm{LW}$, et al: Radiosurgery as a treatment alternative for dural arteriovenous fistulas of the cavernous sinus. AJNR Am J Neuroradiol 19:1081-1087, 1998

11. Hamada Y, Goto K, Inoue T, Iwaki T, Matsuno H, Suzuki S, et al: Histopathological aspects of dural arteriovenous fistulas in the transverse-sigmoid sinus region in nine patients. Neurosurgery 40:452-458, 1997

12. Jung C, Kwon BJ, Kwon OK, Baik SK, Han MH, Kim JE, et al: Intraosseous cranial dural arteriovenous fistula treated with transvenous embolization. AJNR Am J Neuroradiol 30:1173-1177, 2009

13. Jung HH, Chang JH, Whang K, Pyen JS, Chang JW, Park YG: Gamma Knife surgery for low-flow cavernous sinus dural arteriovenous fistulas. J Neurosurg 113 Suppl:21-27, 2010

14. Kida Y: Radiosurgery for dural arteriovenous fistula. Prog Neurol Surg 22:38-44, 2009

15. Klisch J, Kubalek R, Scheufler KM, Zirrgiebel U, Drevs J, Schumacher M: Plasma vascular endothelial growth factor and serum soluble angiopoietin receptor sTIE-2 in patients with dural arteriovenous fistulas: a pilot study. Neuroradiology 47:10-17, 2005

16. Nerva JD, Hallam DK, Ghodke BV: Percutaneous transfacial direct embolization of an intraosseous dural arteriovenous fistula. Neurosurgery 10 (Suppl 1):E178-E182, 2014

17. Pan DH, Lee CC, Wu HM, Chung WY, Yang HC, Lin CJ: Gamma Knife radiosurgery for the management of intracranial dural arteriovenous fistulas. Acta Neurochir Suppl 116:113-119, 2013

18. Pan DH, Wu HM, Kuo YH, Chung WY, Lee CC, Guo WY: Intracranial dural arteriovenous fistulas: natural history and rationale for treatment with stereotactic radiosurgery. Prog Neurol Surg 27:176-194, 2013

19. Pan HC, Sun MH, Sheehan J, Sheu ML, Chen CC, Lee HT, et al: Radiosurgery for dural carotid-cavernous sinus fistulas: Gamma Knife compared with XKnife radiosurgery. J Neurosurg 113 Suppl:9-20, 2010

20. Piske RL, Lasjaunias P: Extrasinusal dural arteriovenous malformations. Report of three cases. Neuroradiology 30:426-432, 1988

21. Sarma D, ter Brugge K: Management of intracranial dural arteriovenous shunts in adults. Eur J Radiol 46:206-220, 2003

22. Shi ZS, Qi TW, Gonzalez NR, Ziegler J, Huang ZS: Combined covered stent and Onyx treatment for complex dural 
arteriovenous fistula involving the clivus and cavernous sinus. Surg Neurol 72:169-174, 2009

23. Shi ZS, Ziegler J, Gonzalez NR, Feng L, Tateshima S, Jahan $\mathrm{R}$, et al: Transarterial embolization of clival dural arteriovenous fistulae using liquid embolic agents. Neurosurgery 62:408-415, 2008

24. Söderman M, Edner G, Ericson K, Karlsson B, Rähn T, Ulfarsson E, et al: Gamma Knife surgery for dural arteriovenous shunts: 25 years of experience. J Neurosurg 104:867875, 2006

25. Söderman M, Pavic L, Edner G, Holmin S, Andersson T: Natural history of dural arteriovenous shunts. Stroke 39:1735-1739, 2008

26. Tanoue S, Goto K, Oota S: Endovascular treatment for dural arteriovenous fistula of the anterior condylar vein with unusual venous drainage: report of two cases. AJNR Am J Neuroradiol 26:1955-1959, 2005

27. Tirakotai W, Bertalanffy H, Liu-Guan B, Farhoud A, Sure U: Immunohistochemical study in dural arteriovenous fistulas and possible role of local hypoxia for the de novo formation of dural arteriovenous fistulas. Clin Neurol Neurosurg 107:455-460, 2005

28. Wu HM, Pan DH, Chung WY, Guo WY, Liu KD, Shiau CY, et al: Gamma Knife surgery for the management of intracranial dural arteriovenous fistulas. J Neurosurg 105 Suppl:43-51, 2006

29. Yang HC, Kano H, Kondziolka D, Niranjan A, Flickinger JC,
Horowitz MB, et al: Stereotactic radiosurgery with or without embolization for intracranial dural arteriovenous fistulas.

Neurosurgery 67:1276-1285, 2010

\section{Disclosures}

The authors report no conflict of interest concerning the materials or methods used in this study or the findings specified in this paper.

\section{Author Contributions}

Conception and design: HM Wu, Lee. Acquisition of data: HM $\mathrm{Wu}$, Lee. Analysis and interpretation of data: Lee. Drafting the article: HM Wu, Lee, CJ Chen, SC Chen, CC Wu. Critically revising the article: $\mathrm{HM} \mathrm{Wu}$, Lee, CJ Chen, SC Chen, Lin, CC $\mathrm{Wu}$. Reviewed submitted version of manuscript: HM Wu, Lee, CJ Chen, SC Chen, Yang, Lin, CC Wu, Pan. Approved the final version of the manuscript on behalf of all authors: HM Wu. Statistical analysis: Lee, CJ Chen, Chung. Administrative/technical/ material support: HM Wu, Lee, Yang, Lin, CC Wu, Chung, Guo, Pan, Shiau. Study supervision: HM Wu, Yang, Lin, Chung, Guo, Pan.

\section{Correspondence}

Hsiu-Mei Wu, Department of Radiology, Taipei Veterans General Hospital, Taipei 11217, Taiwan. email: hmwu@vghtpe.gov.tw. 